\title{
PEDAGOGY
}

\section{SOME OBSERVATIONS ABOUT TEACHING MEDIA LITERACY}

\author{
O. Vysotska, \\ Ph.D., Associate Professor, Ukraine, Kyiv Borys Grinchenko University \\ S. Vysotska, \\ Ph.D., Associate Professor, Ukraine, Kyiv Borys Grinchenko University
}

DOI: https://doi.org/10.31435/rsglobal_ws/30042020/7030

\section{ARTICLE INFO}

Received: 11 February 2020

Accepted: 08 April 2020

Published: 30 April 2020

\section{KEYWORDS}

competences, critical thinking, curriculum, disinformation, media literacy (ML), media education (ME), reflection cycle.

\begin{abstract}
The article highlights the civic/ role of media education that should be taught at schools and universities as a tool for educating responsible and active citizens. It emphasizes that media literacy education should be addressed in primary-secondary-tertiary education level curricula and presents examples of successful teaching and learning practices in the West which are based on competence development approach and active critical engagement of students with media. The article offers for consideration some ways to address disinformation in the classroom, analyzes conditions that make successful implementation of effective media education as well as the challenges media education experiences in Ukraine.
\end{abstract}

Citation: O. Vysotska, S. Vysotska. (2020) Some Observations About Teaching Media Literacy. World Science. 4(56), Vol.3. doi: 10.31435/rsglobal_ws/30042020/7030

Copyright: (C) 2020 O. Vysotska, S. Vysotska. This is an open-access article distributed under the terms of the Creative Commons Attribution License (CC BY). The use, distribution or reproduction in other forums is permitted, provided the original author(s) or licensor are credited and that the original publication in this journal is cited, in accordance with accepted academic practice. No use, distribution or reproduction is permitted which does not comply with these terms.

Introduction. Media literacy is recognized as one of the most essential skills for people living in modern information society. In the conditions of rapid advance of digital technology and the increasing role of the internet in disseminating information, it is urgent for citizens to be able to navigate the huge amount of media production without being drowned in it. Policy making documents of the European Union institutions initiated media literacy awareness campaign and have developed the conceptual background of media literacy education which is considered to be "part of the education for democratic citizenship" and "a particularly important tool in optimizing children's and young people's comprehension, critical thinking, citizenship, creativity and critical awareness of the media" [CE 2013:19-20].

It is widely recognized that today the internet is one the main media tools of communication and sources of information and knowledge. However, the flow of this unfiltered internet information that people have access to poses acute challenges as it may contain harmful, manipulative, misleading, propagandistic, offensive material or hate speech. The spread of propaganda, manipulation and "fake" floods the internet. Then it is quite logical to expect that people should be prepared to counteract them and be able to protect themselves as well as the security of the country, civility, democratic processes and values. Consequently, these challenges demand a response on the part of education and regard media literacy not only as a set of competences for students to develop, but also, in the dimension of agency, as a tool cultivating active forms of citizenship based on democratic values and attitudes [Erasmus +: 6].

Literature review and discussion. The Council of Europe developed a comprehensive resource for media teaching and learning, Reference Framework of Competences for Democratic Culture, which presents areas of competences relevant for a modern democratic society:

1) Values: valuing human dignity and human rights; valuing cultural diversity; valuing democracy, justice, fairness, equality and the rule of law. 
2) Attitudes: openness to cultural otherness and to other beliefs; respect; civic mindedness; responsibility; self-efficacy; tolerance of ambiguity.

3) Skills: autonomous learning skills; analytical and critical thinking skills; skills of listening and observing; empathy; flexibility and adaptability; linguistic, communicative and plurilingual skills; co-operation skills; conflict-resolution skills.

4) Knowledge and critical understanding: of the self; of language and communication; of the world, politics, law, human rights, culture, cultures, religions, history, media, economies, environment, sustainability. [CE 2018a:15-23].

All of them are directly or indirectly related to media literacy education that is based on the system of values and attitudes and contributes to the development of knowledge and skills.

Thus, media literacy is understood as values, attitudes, skills, knowledge, and understanding that allow citizens to use media effectively and safely:

Media-literate people are able to exercise informed choices, understand the nature of content and services and take advantage of the full range of opportunities offered by new communications technologies" [CE 2013:14].

Media-literate people are able to deal adequately with all forms of media messages whether they are in the form of a written text, sound or image and should be able to:

- Use media technologies effectively to access, store, retrieve and share content to meet their individual and community needs and interests;

- Gain access to, and make informed choices about a wide range of media forms and content from different cultural and institutional sources;

- Understand how and why media content is produced;

- Analyze critically the techniques, languages and conventions used by the media, and the messages they convey;

- Use media creatively to express and communicate ideas, information and opinions;

- Identify, and avoid or challenge, media content and services that may be unsolicited, offensive or harmful;

- Make effective use of media in the exercise of their democratic rights and civic responsibilities" [Frau-Meigs \& Torrent: 20-21].

In other words, as media experts sum up, media literacy education develops important competences - the 6 C's: Comprehension, Critical Capacity, Creativity, Consumption, Citizenship and Cross-Cultural Communication [Ib.: 20-21].

Thus, Media Literacy classes help students develop critical reading skills, get insight into information for them to be able to see and understand "behind the visible". It "fosters educational environments in which students can practice the skills of leadership, free and responsible selfexpression, conflict resolution, and consensus building" [Akar-Vural :741-742]. Together with developing digital technology skills and, so-to-say, "bridging the digital divide", the main rationales for promoting media education are civic participation, empowerment, protection from harmful content, informed decision-making, understanding social responsibility and one's own identity, and, in the result, becoming political agents in a democratic society [CE 2013:8]. "Engaging in citizenship through digital technologies" is defined as "to participate in society through the use of public and private digital service and to seek opportunities for self-empowerment and for participatory citizenship through appropriate digital technologies" (Vuorikari et al:8). Media literacy raises civic awareness and encourages increased participation in civil society [McDougall et al.: 16].

Media education practice is gaining momentum in Ukraine too, with more and more people understanding that it should become a part of every person's general literacy. Recently there have appeared online courses, conferences and workshops on media education and media literacy which help people counteract bias, manipulation and propaganda in the war-torn Ukraine. The war in the country has lasted for 6 years. It was unleashed against Ukraine in 2014 and it is still going on, with the cost of 13 thousand Ukrainian killed, thousands of wounded and crippled, 1.5 IDPs, thousands of ruined houses, robbed and destroyed businesses, and one eighth of the territory occupied by the aggressor. However, there are people in the country, attacked by the aggressor, who do not even know that the war is going on and do not care; there are others who completely forget about victims and sacrifices and agree to making peace at all costs; they speak about the civil war in the east of Ukraine and accuse Ukraine itself in unleashing the war. The question arises why the enemy's propaganda is so powerful and effective, why such things can happen in the country which has been independent for 30 years after the disintegration of the USSR. 
It seems to be logical to connect the problem with the absence of media literacy and insufficient media education in Ukraine, where a number of citizens are unable to resist the powerful propaganda of the enemy which is a component of the war against Ukraine - the hybrid war. This new kind of war blends conventional war with other methods, such as fake news, diplomacy, lawfare and foreign electoral intervention to destabilize the opponent [Standish].

However, media education attracted attention in Ukraine, and in 2015-2016 an experiment of teaching media Literacy at some secondary schools was conducted in the country. The results were presented in the Analytical Report commissioned by Ukrainian Media Project (U-Media Program) and implemented by Internews Network Kyiv [Implementation 2016]. The report presents the main problems connected with teaching and learning media literacy as it was outlined by teachers participating in the experiment. The problems are as follows:

Lack of basic ME/ML course outlines for different grades

Limited number of school hours to teach ME/ML course

Lack of ME/ML textbooks for pupils and practical materials

Lack of modern equipment (multimedia) to teach $M E / M L$

Lack of control materials of $M E / M L$

Lack of interest and indifference of pupils

Lack of ME/ML teacher guides

School administration's lack of interest

Limited opportunity for sharing experience with other ME/ML teachers and organizations

State's indifference towards the experiment organization and content filling of the $M E / M L$ teaching process in secondary schools

The opponents may argue and claim that Media Literacy has been taught at Ukrainian secondary schools as elements of Technology, Civil Education, IT, and some other subjects, but it is impossible to speak about a positive result of the process of Media Education teaching / learning developed media literacy skills of the young generation.

As a rule, children and adolescents are prioritized when administering media education, and university students should not be aloof. However, the result of inadequate media education at school, former school students come to universities and declare that they are not interested in politics, in the state policy, in the situation at the front despite the fact that the defensive war is still going on, and every day defenders of the country are killed and wounded; students are not against going to the aggressor's country, watching aggressor's films, listening to aggressor's music, etc. They do not think that such behaviour is a kind of betrayal. Older people claim that there is no difference for them whether there is a monument to a Ukrainian hero or to the enemy in their city. It does not matter whether people around them are patriots of Ukraine or they support the enemy, whether the native language of the country is preserved or it is replaced by the aggressor's one.

Analyzing the experience of western countries in administering media education may help develop media literacy in Ukraine which will definitely strengthen citizenship and patriotism of Ukrainians and may answer a lot of questions the country is facing today. Moreover, media education will help solve lots of problems Ukrainian education system faces and should address:

teaching and learning practices that support the development of students' media literacy and facilitate their critical engagement with media; developing their ability of critical reading when deciphering media messages; cultivating active citizenship of students and ability to oppose disinformation; identifying media education literacy practices which are the most effective and suitable for different stages of education; promoting media literacy in the country and integrating media literacy in the curriculum; training for teachers who are involved in teaching the subject; administering and practicing formal education as well as out-of-class activities and national campaigns.

Today digital literacy skills of Ukrainian students are quite well developed. The overwhelming majority of them have smart phones, computers, access to the Internet, etc.; they widely use social networks, Instagram, various computer programs and applications. They are active international team gamers. In general, students possess developed technical skills required for that. However, they demonstrate low ability to reflect on the information obtained; the skills required for critical evaluation of this information, their awareness of biased information, fakes, and manipulation are definitely insufficient.

Other European countries experience challenges and problems in the area of media literacy education too. In 2014, the EMEDUS (European Media Literacy Education Study) project underlined that media education is left out of ITE (initial teacher education) in Europe [CE 2013:61], that there is 
no formal teacher training in media education which remains to be at the "mercy of individual teachers" [Hartai:140]:

Teachers' pedagogic expertise in these areas is dependent on their own interest in seeking out professional development and the availability of such training in their regions or nations. Most media literacy education training is provided as part of informal networks or as a feature of projects funded by non-governmental sources [Erasmus $+: 61$ ].

In more advanced in terms of media literacy European countries, media literacy skills are developed directly at schools as well during students' free time. However, one of the most important features of media education is that it is included into school curricula though schools enjoy autonomy in making their decisions concerning media studies. Media education appears as a separate subject, or as media literacy interventions delivered in a fragmented, modular, or cross-curricular way being incorporated into teaching other subjects, with the latter predominating. It may be integrated into courses of teaching Mother Tongue, History, Geography, Civic and Citizenship Education or Science. However, as Frau-Meigs points out that teaching Media Literacy across the curriculum may deprive it of its focus: "an issue that is every teachers' responsibility can quickly become nobody's responsibility" [Frau-Meigs 2006:14].

In such English-speaking countries as the UK, Australia, Canada as well as in the Netherlands media education is well-established at secondary schools. They started teaching Media Studies, which is included into curricula from elementary school through higher education, in the middle of the 20th century [Akar-Vural; Belova and Eilks; Hobbs and Jensen]. Though, it is not taught as an independent mandatory subject in any European country, it is attached to Mother Tongue, Visual Arts, Civic and Citizenship Education, Social Studies, History or ICT. For example, in Germany, standards for media literacy for the primary and secondary school have been developed at the national level as long as in the 1990s. Media literacy as "the ability and the willingness to deal with media in an adequate, autonomous, creative and socially responsible way" (Tulodziecki: 49) is part of the curriculum though it is taught mostly as a noncompulsory course. In the Netherlands, Media Education as development of internet skills, critical understanding and reflective competences is implemented by enthusiasts at school level [Küter-Luks].

In one of the most advanced European countries as media education is concerned, the UK, Media Education is included into the mainstream curriculum. It is represented at the minimal level at primary school; at the secondary school there are media education specialist courses, available to students who are able to develop particular media literacy skills: enquiry, critical thinking, decisionmaking and analysis; knowledge and understanding of a range of important media issues; appreciation and critical understanding of the media and their role; and practical skills for creative media production [Department of Education]. The subject is taught mostly by language teachers, and medium literacy skills are assessed for getting the General Certificate of Secondary Education. Moreover, Media Studies and Film Studies courses are available at more than 100 higher education institutions.

Some European countries, for instance, the Czech Republic, Finland, and Spain focus mostly on developing digital literacy competences when dealing with media literacy [Erasmus +: 55]. Though, what is especially important for Ukraine, media literacy is not only about utilizing modern technology. It often happens that students master digital skills by themselves, asking peers for help, observing others. They can easily get necessary information. However, their ability to critically evaluate the information and internet sources is low, and they should be taught what to do with the information received, to read it critically, to reflect on it, to understand what is true and what is fake and manipulation. Students should be responsible for their positions and points of view and take into account opinions of others. For this purpose, the main focus in media literacy teaching and learning should be on developing specific media literacy competencies: on the basis of the application of the Inquiry Cycle (ask-investigate-create-discuss-reflect-ask again) - access to, analysis and evaluation, creation and reflection on the information [Casey and Bruce:80].

European experience evidences that the most effective results in media studies may be achieved with active learning and such forms of classroom activities as cooperative work, project work, drama activities, role plays, discussions, etc. Through the usage of pedagogical practices that teach students to doubt the information and to ask specific questions about it and media messages they received, questions that develop students' active inquiry and critical thinking: the message author's motives and purpose, the language employed, the socio-cultural context the massage was created in, etc. [Hobbs \& McGee]. The teacher directs the process of learning, asking questions which stimulate inquiry, promoting reflection and 
critical thinking, and guiding discussion. Such activities may be employed if and when discussions of newspaper articles, films, TV shows, etc. have become a part of the classroom culture.

On the other hand, such activities place extra burden on teachers demanding from them to challenge students' values and believes directly that may cause strong resistance and defense on the part of students. Thus, their bias may be fortified. Students tend to believe information they get and do not consider alternative points of view. This may lead them into a filter bubble and cause "a backfire effect" - strong resistance on their part. Some recommendations to teachers who initiate and raise topics for discussions may be given and considered:

Find the facts before you come to any conclusion;

Be aware of today's propagandas associated with issued discussed and your own bias;

Be ready to provide credible explanation;

Help students get insight into the issue;

Demonstrate the necessity to triangulate and get information from a wide range of sources to analyze different opinions;

Behold your own reaction to conflict elements;

Guard against omnibus words; doubt your own opinions;

Withhold judgements if you feel that is required by the situation [Erasmus +: 45].

There are multiple initiatives and interesting forms and techniques in media education practices have been developed, for example, Lie Detectors organization which is active In Germany and Belgium. Its aim is to turn schoolchildren into "lie detectors", develop their reflective skills, critical thinking, and ability to analyze information in a deeper and critical way, to make informed choices and resist "the pressure of peers" [Ibid].

Some media educators practice the so-called "inoculation" method - "inoculation" of youth for fake news. It is like inoculation for a virus. "Students are exposed to a "weakened" form of the disinformation. When exposed to the disinformation at a later date, the inoculation will provide them with the necessary counter-arguments to dismiss the disinformation" [Ibid.].

In the UK and the Netherlands students try their hand in creating fake news, playing an online simulation game that puts players in the shoes of manipulators and fake news developers, thus making them resistant to fakes and propaganda [Op. Cit.: 47]. Professional journalists may be involved in the teaching process.

Summing up and concluding, it is worth remarking that teaching English at school as well as at universities has huge potential in terms of teaching Media Literacy. Media literacy education may be successfully integrated into the course of Foreign Language teaching too and help raise students' awareness of the nature of information they receive as a foreign language command gives students an opportunity to get extra channels to exchange information, extra sources of getting information from and an opportunity to triangulate. Foreign language teachers themselves have always been among innovators, those who have a broader access to authentic information and, thus, those who have a broad outlook. They may and should play a greater role in turning consumers of information into critically-minded users of this information who are able to analyze it and understand bias and manipulation.

However, a lot depends on the position of authorities and policymakers of the country - the government and the Ministry of Education. If they think strategically, understand the role of critically thinking citizenry and are interested in developing and strengthening civil society in the country, they will provide adequate support to media educators with resources, equipment, finance, etc. If the leaders of the country want to stand the information aggression, win the hybrid war, and preserve the identity of the country, the following steps may be recommended:

- Teaching media literacy as a separate subject or a compulsory component of a number of other subjects; it should be included into curricula and syllabuses.

- Administration of proper control over the process of teaching media literacy.

- Dissemination of best practices based on active inquiry, collaborative learning, discussionbased learning, etc.

- Introduction of formal training for media education teachers.

- Arrangement of out-of-class activities not only for students, but for all layers of society.

- Creation of favourable and supporting school environment.

Moreover, one of the first and the most important steps in developing media literacy is raising awareness of disinformation and its misuse among society members. 


\section{REFERENCES}

1. Akar-Vural, R. (2010). 'How Rural Schoolchildren and Teachers Read TV Dramas: A Case'. Urban Education, 45(5), 740-763. https://doi.org/10.1177/0042085910377289

2. Belova, N., \& Eilks, I. (2015). 'Learning with and about Advertising in Chemistry Education with a Lesson Plan on Natural Cosmetics: A Case Study'. Chemistry Education Research and Practice, 16(3), 578-588. https://pubs.rsc.org/en/content/articlehtml/2015/rp/c5rp00035a

3. Casey, L., \& Bruce, B. C. (2011). 'The Practice Profile of Inquiry: Connecting Digital Literacy and Pedagogy'. E- Learning and Digital Media, 8(1), https://journals.sagepub.com/doi/pdf/10.2304/elea.2011.8.1.76

4. Council of Europe (2013). IRIS plus. Media Literacy. Volume 3, 80. Pdf

5. Council of Europe (2018a). Reference Framework of Competences for Democratic Culture. Volume 1: Context, concepts and model. Strasbourg: Council of Europe Publishing. https://rm.coe.int/prems-008418gbr-2508-reference-framework-of-competences-vol-2-8573-co/16807bc66d Pdf 85 p.

6. Council of Europe (2018b). Reference Framework of Competences for Democratic Culture. Volume 2: Descriptors of competences for democratic culture. Strasbourg: Council of Europe Publishing. https://rm.coe.int/prems-008418-gbr-2508-reference-framework-of-competences-vol-2-8573co/16807bc66d Pdf. 57 p.

7. Frau-Meigs D. \& Torrent J. (2009) “Media Education Policy: Towards a Global Rationale", in Divina FrauMeigs \& Jordi Torrent, Eds. Divina Frau-Meigs \& Jordi Torrent, "Media Education Policy: Towards a Global Rationale", in Divina Frau-Meigs \& Jordi Torrent, Eds., Frau-Meigs, Divina, and Jordi Torrent. "Media education policy: towards a global rationale." Comunicar, vol. 16, no. 32, 2009, p. S15+. Pp. 15-21. https://pdfs.semanticscholar.org/93ec/d585f9a0fe210469aab4bcb6f4d71ef95d28.pdf?_ga=2.221726364.506 624902.1584040774-279838261.1584040774

8. Frau-Meigs, D. (2006). Media Education: A Kit for Teachers, Students, Parents and Professionals. Paris: UNESCO. https://unesdoc.unesco.org/ark:/48223/pf0000149278 185 p.

9. Erasmus + (2018). Teaching media literacy in Europe: evidence of effective school practices in primary and secondary education. Analytical report. Luxembourg: Publications Office of the European Union. 91 p.

10. https://nesetweb.eu/wp-content/uploads/2019/06/AR2_Full_Report_With_identifiers_Teaching-MediaLiteracy. Pdf

11. Hartai, L. (2014). 'Report on Formal Media Education in Europe' (WP3), European Media Literacy Education Study (EMEDUS), Lifelong Learning Programme. Available at: https:/eavi.eu/wpcontent/uploads/2017/02/Media- Education-in-European-Schools-2. Pdf

12. Hobbs R. \& A. Jensen (2009). The Past, Present, and Future of Media Education. The National Association for Media Literacy Education's Journal of Media Literacy Education 1 (2009) 1-11. Available online at www.jmle.org

13. Hobbs, R., \& McGee, S. (2014). 'Teaching about Propaganda: An Examination of the Historical Roots of Media Literacy'. Journal of Media Literacy Education, 6(2), 56-66.

14. https://digitalcommons.uri.edu/cgi/viewcontent.cgi?article=1207\&context=jmle

15. Küter-Luks, T., Heuvelman, A. \& Peters, O. (2011). 'Making Dutch pupils' media conscious: preadolescents' self- assessment of possible media risks and the need for media education'. Learning, Media and Technology, 36(3), 295-313. https://doi.org/10.1080/17439884.2010.549826

16. Implementation of media education and media literacy courses in secondary schools in Ukraine. (2016). Analytical Report on the Results of Complex Study conducted during 2014-2016, commissioned by Ukrainian Media Project (U-Media Program) implemented by Internews Network Kyiv, 26p. https://www.slideshare.net/umedia/mediaeducation-in-ukrainian-schools-analitycal-report-english-translation-2016

17. McDougall, J., Livingstone, S. \& Sefton-Green, J. (2014). 'Media and Information Education' in the UK: Report for Cost/ANR. http://eprints.lse.ac.uk/57103/1/Livingstone media information literacy 2014 author. Pdf

18. Standish, Reid (2018-01-18). "Inside a European Center to Combat Russia's Hybrid Warfare". Foreign Policy. https://foreignpolicy.com/2018/01/18/inside-a-european-center-to-combat-russias-hybrid-warfare/

19. The National Curriculum in England: Key stages 3 and 4 framework documents: The secondary national curriculum programmes of study and attainment targets for key stages 3 and 4 . | LAST UPDATE VERSION - December 23, 2019.106 p. Pdf.

20. Tulodziecki, G., \& Grafe, S. (2012). 'Approaches to Learning with Media and Media Literacy Education-Trends and Current Situation in Germany'. Journal of Media Literacy Education, 4(1), 44-60. https://files.eric.ed.gov/fulltext/EJ985678 Pdf

21. Vuorikari, R., Punie, Y., Carretero Gomez S. \& Van den Brande, G. (2016). 'DigComp 2.0: The Digital Competence Framework for Citizens'. Update Phase 1: The Conceptual Reference Model. Luxembourg Publication Office of the European Union. EUR 27948 EN. Doi:10.2791/11517. 40p. https://publications.jrc.ec.europa.eu/repository/bitstream/JRC101254/jrc101254_digcomp\%202.0\%20the\% 20digital\%20competence $\% 20$ framework $\% 20$ for $\% 20$ citizens. $\% 20$ update $\% 20$ phase $\% 201$. Pdf 